\title{
A randomized study to assess the efficacy of herbal product to prevent cisplatin-induced nephrotoxicity in a rat model
}

\author{
Eyup Veli Kucuk ${ }^{1}$, Ahmet Bindayi ${ }^{2}$, Meral Mese ${ }^{3}$, Funda Gulcu Bulmus ${ }^{3}$, Ergun Parmaksız ${ }^{3}$, \\ Ali Cihangir Cetinel ${ }^{4}$, Zerrin Bicik Bahcebasi ${ }^{3}$, Kemal Sarica ${ }^{4}$ \\ ${ }^{1}$ Umraniye Training and Research Hospital Urology Clinic, Istanbul, Turkey; \\ ${ }^{2}$ Bahcesehir University Department of Urology, Istanbul, Turkey; \\ ${ }^{3}$ Dr. Lütfi Kirdar Training and Research Hospital Nephrology Clinic, Istanbul, Turkey; \\ ${ }^{4}$ Dr. Lütfi Kirdar Training and Research Hospital Urology Clinic, Istanbul, Turkey.
}

\begin{abstract}
Summary Objectives: This study aimed to investigate the protective effect and antioxidant activity of an herbal product that made from multiple plants in a rat model of kidney dysfunction induced by intraperitoneal cisplatin. Materials and methods: Twenty-four rats were divided into four different groups namely: Group 1 - control healthy animals without any specific medication, Group 2 - Herbal product only $5 \mathrm{mg} / \mathrm{kg}$, Group 3 - cisplatin only and Group 4 - Herbal product $5 \mathrm{mg} / \mathrm{kg}+$ cisplatin.

Results: Evaluation of our findings demonstrated a significant $(p=0.017)$ reduction in Catalase activities and a significant increase $(p=0.001)$ in renal tissue Malondialdehyde levels in cisplatin- treated rats when compared with the control group. Also, Glutathion and Glutathione peroxidase content revealed significant $(p=0.031)$ reduction in renal tissues of cisplatintreated rats compared with the control group. Pre-treatment of rats with the herbal product ameliorated these cisplatininduced changes of the antioxidant enzymes. No statistically significant changes were demonstrated in Superoxide dismutase activities in the tissue specimens of any group.

Conclusions: This potent antioxidant herbal medicine was found to have potential antioxidant activity, which may in turn to be effective in the protection of kidney tissue resulting from cisplatin application. Therefore, much attention should be given to the possible role of natural dietary antioxidants for protecting the kidney.
\end{abstract}

KeY wORDS: Animal model; Antioxidants; Cisplatin; Herbal medicine; Nephrotoxicity.

Submitted 30 May 2017; Accepted 2 July 2017

\section{INTRODUCTION}

Despite their well-established curative effects in certain solid organ tumors, chemotherapeutic agents may exhibit dose dependent toxic effects during the course of chemotherapy on certain organ systems, a reality that should inevitably be taken into account by all physicians. Cisplatin ${ }^{\circledR}$ (cis-diamminedichloroplatinum II) is one of the most widely used chemotherapeutic drugs for the treatment of various solid tumors, including those of the breast, head, neck, lung, testis, bladder and ovary (1). Of these side effects, nephrotoxicity is the most well-known, established and clinically important toxicity of this drug (2).

Over the last few decades, different studies were made to investigate the pathophysiological basis of cisplatininduced nephrotoxicity and how to protect kidney from this toxicity. These studies demonstrated number of mechanisms including oxidative stress, DNA adducts, inflammation, mitochondrial dysfunction, and direct cytotoxicity to the tubular epithelial cells (2-4). Also literature revealed that Cisplatin ${ }^{\circledR}$ application might cause renal vasoconstriction that reduces blood flow, causing ischemic damage to the kidney and deteriorate the glomerular filtration rate. These alterations eventually trigger ischemia-induced oxidative stress, a well-known phenomenon that ultimately results in renal tubular cell injury and death. Cisplatin ${ }^{\circledR}$ administration in a mice model resulted in marked renal failure characterized by a significant increase in serum urea and creatinine levels due to the formation of oxidative stress as indicated by increased lipid peroxidation and decreased levels of glutathione (GSH), glutathione peroxidase (GSHPx), superoxide dismutase (SOD) and catalase in renal tissues $(5,6)$. Being aware of the well-known side effects of Cisplatin ${ }^{\circledR}$ on the functional and morphological integrity of the kidneys, physicians began to look for protective agents to prevent or at least limit the extent of the renal toxic effects of Cisplatin ${ }^{\circledR}$ based chemotherapy. Related to this issue, evaluation of literature data demonstrated that AsAG or TMG, lutein, ascorbic acid and alpha tocopherol may reduce cisplatin-induced renal toxicity either by limiting the extent of renal functional deterioration or increasing the antioxidant capacity of the kidneys $(3,4,7,8)$.

On the other hand, in addition to the use of these medical agents, recent data demonstrated that phytotherapy might prevent toxic effects of certain medications causing morphologic as well as functional changes in different organ systems $(3,4,8-10)$. In this study, we investigate the potential renoprotective effects of a herbal medication $\left(\right.$ Tutukon ${ }^{\circledR}$ ) on cisplatin-induced oxidative stressrelated nephrotoxicity in a rat model. 


\section{Methods}

\section{Animals}

This study was made with 24 male Wistar white rats, each weighing 250-300 g. Ethical committee approval (No: 94-14/2013) was obtained from the animal laboratory of the Pendik Animal Research Laboratory (Istanbul, Turkey) and all procedures performed in studies involving animals were in accordance with the ethical standards of the institution or practice at which the studies were conducted. All animals were fed standard chow and kept under normal room conditions at a constant temperature $\left(25^{\circ} \mathrm{C}\right)$ under a 12 hours light/dark cycle. Rats underwent a complete physical examination, biochemical evaluation including blood and urine analyses and stool examination.

We estimated that total of 24 subjects would be needed to detect difference among groups with $\alpha$ of 0.05 and a (1- $\beta$ ) of $80 \%$. Rats randomly divided into four groups (each with $\mathrm{n}=6$ ): Group 1 (control group) received only standard rat chow and distilled drinking water without any specific medication. Group 2 (Tutukon ${ }^{\circledR}$ group) received an herbal product $\left(\right.$ Tutukon $\left.^{\circledR}\right)$ given via a feeding catheter $(20 \mathrm{ml} / \mathrm{kg}$ ). Group 3 (Cisplatin group) received Cisplatin ${ }^{\circledR}$ only $(7.5 \mathrm{mg} / \mathrm{kg}$ once i.p.). Group 4 (Tutukon ${ }^{\circledR}+$ Cisplatin $^{\circledR}$ group) received a combined medication $\left(20 \mathrm{ml} / \mathrm{kg}\right.$ of Tutukon ${ }^{\circledR}$ for seven days $+7.5 \mathrm{mg} / \mathrm{kg}$ Cisplatin ${ }^{\circledR}$ i.p. after seven days for once). Control group animals received only distilled drinking water during all study phases. After two weeks bilateral nephrectomy was performed with bilateral flank incision. All surgery was performed under sodium pentobarbital anesthesia, and all efforts were made to minimize suffering.

\section{Main chemicals and drugs}

Cisplatin ${ }^{\circledR}$ was used to induce nephrotoxicity in rats according to the method of Prabhu et al. (11).

Applied dose was $7.5 \mathrm{mg} / \mathrm{kg}$ rat body weight (intraperitoneal).

Plant-based herbal medication (Tutukon ${ }^{\circledR}$ ) fixed-dose combination. Dosage form: hydrolate, bottles of $600 \mathrm{ml}, 45 \mathrm{ml}$ three times/daily. Ingredients: Essential oils, flavonoids-quercetin, polysaccharides, rosemarinic acid, boldin, flavonglicozides. Composition (per $100 \mathrm{ml}$ of solution): Enguisetumarvensis $570 \mathrm{mg}$, Spergulariarubra $330 \mathrm{mg}$, Peumusboldus $280 \mathrm{mg}$, Opuntiaficusindica $170 \mathrm{mg}$, Sideritisangustifolia 170 mg, Rozmarinusofficinales 170 mg, Cynodondaktylon $170 \mathrm{mg}$, Melissa officinalis $170 \mathrm{mg}$.

\footnotetext{
Measurement of Malondialdehyde (MDA) and glutathione levels, Superoxide dismutase (SOD) and catalase (CAT) activities in renal homogenate

The homogenization of tissues was carried out in a Teflon-glass homogenizer with a buffer containing $1.15 \% \mathrm{KCl}$ to obtain 1/10 (w/v) whole homogenate. MDA levels were directly measured in the
}

Figure 1. homogenates. The homogenates were centrifuged for 30 min at $25000 \mathrm{~g}$ at $+4^{\circ} \mathrm{C}$ to determine GSH-Px and CAT activities. The obtained supernatants were centrifuged again at $25000 \mathrm{~g},+4^{\circ} \mathrm{C}$ for $30 \mathrm{~min}$ to determine SOD activities. The MDA concentrations of tissue homogenates were measured according to a modified method from Ohkawa et al. (12) based on the reaction with TBA and the results were expressed as nmol/g protein. The GSH-Px activities were determined according to the method of Beutler, (13) which records the disappearance of NADPH at $340 \mathrm{~nm}$, and results were expressed as U/g protein. The CAT activities were determined by measuring the decomposition of hydrogen peroxide at $240 \mathrm{~nm}$, according to the method of Aebi (14).

The results were expressed as $\mathrm{k} / \mathrm{g}$ protein, where $\mathrm{k}$ is the first-order rate constant. SOD activities were determined using the method of Sun et al. (15) and the results were expressed as U/g protein. Tissue GSH concentrations were measured by an assay using the dithionitrobenzoic acid recycling method described by Elman (16) and expressed as $\mathrm{nmol} / \mathrm{mg}$ protein. Protein concentrations were measured according to Lowry et al. (17).

\section{Statistical analysis}

For statistical analysis of the obtained data NCSS (Number Cruncher Statistical System) 2007\&PASS (Power Analysis and Sample Size) 2008 Statistical Software (Utah, USA) program was used. The data was expressed in mean +/standard deviation. Mann-Whitney $U$ and Kruskal-Wallis tests were used to compare the parameters between two or more groups that don't fit to normal distribution. A P value of $<0.05$ was considered as significant.

\section{RESULTS}

Evaluation of the tissue enzyme levels demonstrated the following findings (Figure 1).

MDA, CAT, GSH-Px and kidney GSH levels according to the groups.

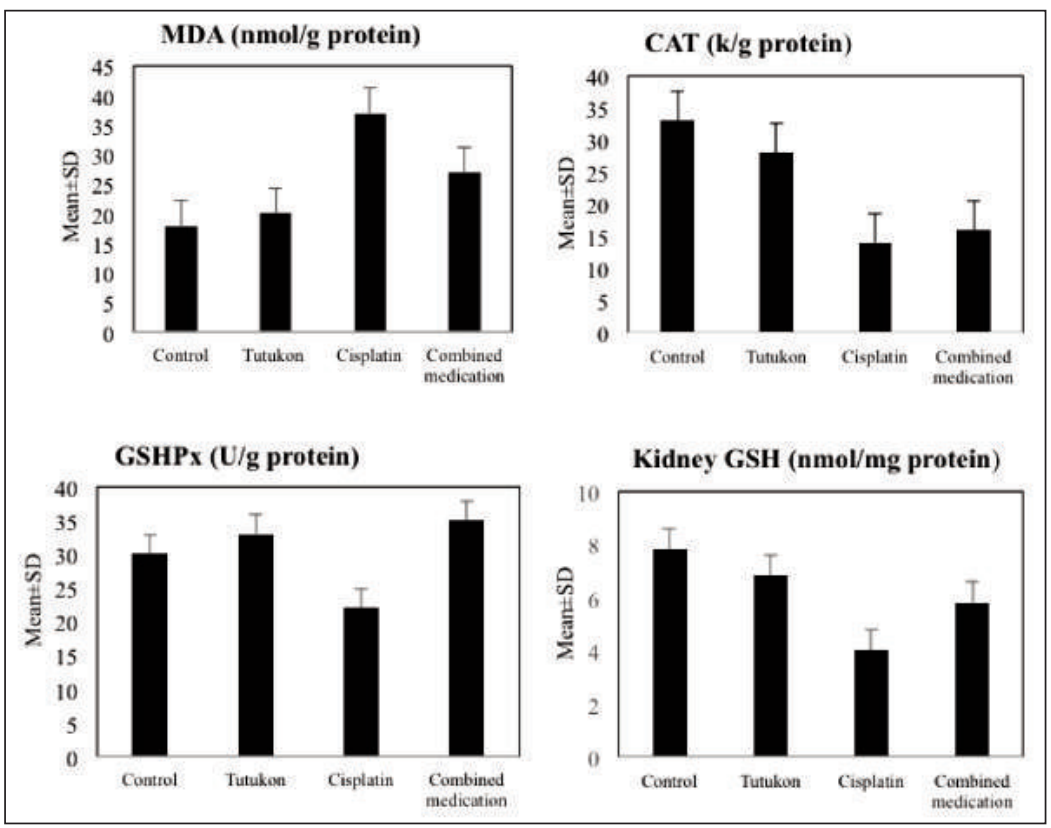


MDA: There were statistically significant differences among groups regarding levels of MDA ( $p<0.001)$ (Table 1). There was a significant increase in renal tissue MDA levels in cisplatin-treated rats (Cisplatin ${ }^{\circledR}$ only or Tutukon ${ }^{\circledR}+$ Cisplatin $^{\circledR}$ ) compared with the control and Tutukon ${ }^{\circledR}$ groups $(p<0.05)$. There was no statistically significant difference with respect to MDA levels between the Tutukon ${ }^{\circledR}$ and control groups. Lastly, although not statistically significant, renal tissue MDA levels of the Tutukon + Cisplatin ${ }^{\circledR}$ group were found to be comparably lower than the Cisplatin ${ }^{\circledR}$ group $(\mathrm{p}=0.055)$ (Table 2).

SOD: There were no statistically significant differences among groups regarding SOD activities ( $p>0.05)$ (Table 1 and 2).

CAT: CAT activity of the cisplatin-treated rats (Cisplatin ${ }^{\circledR}$ only or Tutukon ${ }^{\circledR}+$ Cisplatin $^{\circledR}$ ) was lower than the other groups (Figure 1). The combined medication group showed significantly lower CAT activity than the control and Tutukon ${ }^{\circledR}$ groups ( $\mathrm{p}=0.025, \mathrm{p}=0.016$, respectively). According to comparative studies, CAT activity of the Cisplatin ${ }^{\circledR}$ group was significantly lower than the control group $(p=0.037)$. It was also found to be lower but not statistically significant than the Tutukon ${ }^{\circledR}$ group $(\mathrm{p}=0.055)($ Table 2).

GSH-Px: There was statistically significant difference of GSH-Px levels among groups $(\mathrm{p}=0.031$ ) (Table 1). According to dual-comparison of the groups, GSHPx levels in the Cisplatin $^{\circledR}$ group showed significant reduction compared with Tutukon ${ }^{\circledR}$ and combined medication groups ( $\mathrm{p}=0.037, \mathrm{p}=0.016$, respectively) (Table 2 ).

GSH: There were statistically significant differences among groups for GSH levels ( $\mathrm{p}=0.007$ ) (Table 1 ). According to dual comparison results, GSH levels of the Cisplatin ${ }^{\circledR}$ group were significantly lower than the Tutukon ${ }^{\circledR}$ and combined medication groups $(\mathrm{p}=0.010$, $\mathrm{p}=0.037$, respectively) (Table 2 )

\section{Table 1.}

The evaluation of MDA, SOD, CAT, GSH-Px and kidney GSH.

\begin{tabular}{|c|c|c|c|c|c|}
\hline & $\begin{array}{c}\text { MDA } \\
\text { (nmol/g protein) } \\
\text { Mean } \pm \text { SD }\end{array}$ & $\begin{array}{c}\text { SOD } \\
\text { (U/g protein) } \\
\text { Mean } \pm \text { SD }\end{array}$ & $\begin{array}{c}\text { CAT } \\
\text { (k/g protein) } \\
\text { Mean } \pm \text { SD }\end{array}$ & $\begin{array}{c}\text { GSH-Px } \\
\text { (U/g protein) } \\
\text { Mean } \pm \text { SD }\end{array}$ & $\begin{array}{c}\text { Kidney GSH } \\
\text { (nmol/mg protein) } \\
\text { Mean } \pm \text { SD }\end{array}$ \\
\hline Control & $18.62 \pm 2.21$ & $50.87 \pm 9.22$ & $30.22 \pm 11.3$ & $30.21 \pm 8.87$ & $7.76 \pm 1.56$ \\
\hline Tutukon ${ }^{\circledR}$ & $19.89 \pm 3.73$ & $48.55 \pm 10.56$ & $26.90 \pm 4.99$ & $32.02 \pm 5.79$ & $6.68 \pm 1.49$ \\
\hline Cisplatin $^{\circledR}$ & $35.47 \pm 7.04$ & $38.75 \pm 16.62$ & $14.86 \pm 10.63$ & $22.14 \pm 7.95$ & $4.19 \pm 0.82$ \\
\hline Tutukon $^{\circledR}+$ Cisplatin ${ }^{\circledast}$ & $27.10 \pm 4.95$ & $47.19 \pm 18.59$ & $16.30 \pm 4.85$ & $35.45 \pm 6.02$ & $5.85 \pm 1.41$ \\
\hline${ }^{a} \mathbf{p}$ & $0.001 * *$ & 0.667 & $0.017 *$ & $0.031 *$ & $0.007^{* *}$ \\
\hline
\end{tabular}

Table 2.

Dual comparison of groups.

\begin{tabular}{|c|c|c|c|c|c|}
\hline & MDA & SOD & CAT & GSH-Px & Kidney GSH \\
\hline Group 1 vs Group $2^{b}$ & 0.749 & 0.749 & 0.522 & 0.631 & 0.262 \\
\hline Group 1 vs Group $3^{b}$ & $0.004 * *$ & 0.200 & $0.037 *$ & 0.109 & $0.006 * *$ \\
\hline Group 1 vs Group $4^{b}$ & $0.006 * *$ & 0.873 & $0.025 *$ & 0.262 & 0.055 \\
\hline Group 2 vs Group $3^{b}$ & $0.004^{* *}$ & 0.337 & 0.055 & $0.037 *$ & $0.010 *$ \\
\hline Group 2 vs Group $4^{b}$ & $0.037^{*}$ & 0.873 & $0.016 *$ & 0.337 & 0.423 \\
\hline Group 3 vs Group $4^{b}$ & 0.055 & 0.522 & 0.109 & $0.016^{*}$ & $0.037 *$ \\
\hline
\end{tabular}

\section{Discussion}

Cisplatin ${ }^{\circledR}$ is a chemotherapeutic agent widely used for the treatment of various solid cancers. However, nephrotoxicity is one of the major side effects of Cisplatin ${ }^{\circledR}$ and published data have shown that an estimated 20\% of patients receiving high-dose Cisplatin ${ }^{\circledR}$ suffer severe renal dysfunction and approximately one third of patients may experience kidney injury following initial treatment (18, 19). Renal tubular injury and cell death are the most prominent pathologic findings originating from reduced blood flow (ischemia) induced oxidative stress in renal tubular cells following the application of this agent.

In literature, several mechanisms were documented to be important in renal tubular injury. Yonazewa et al. showed that organic cation transporter 2 (OCT2) mediates the entry of Cisplatin ${ }^{\circledR}$ into the renal tubular cells and stimulate the sensitivity of Cisplatin $^{\circledR}$ in these cells. Cisplatin ${ }^{\circledR}$ reduces the activity of mitochondrial respiratory complexes, resulting in reactive oxygen species (ROS) generation (20). The other mechanism of generation of reactive oxygen species is depletion of endogenous antioxidant, glutathione. Cisplatin ${ }^{\circledR}$ may damage the kidney by depletion of critical sulfhydryl centers, including GSH inside the cells, and may provoke damage to the cell by generating a cascade of lipid membrane peroxidation, mitochondrial dysfunction and DNA injury which reduces the internal antioxidant storages $(21,22)$. Likewise in our study we found that Cisplatin ${ }^{\circledR}$ treatment decreased GSH, GSHPx levels, CAT activites and increased MDA levels.

Thus, all these findings clearly have shown that cisplatininduced generation of ROS, cytokines and chemokines are directly related to its cytotoxicity. ROS produce by the xanthine-xanthine oxidase system, mitochondria, and NADPH oxidase in cells. Following treatment with Cisplatin $^{\circledR}$, ROS that produced throughout these systems, are implicated in the pathogenesis of acute renal injury (22).

Related to this subject, in their original study both Maliakel and Atasayar et al. showed that administration of AsAG or TMG markedly reduced the cisplatininduced higher plasma creatinine and urea levels and counteracted the deleterious effects of formed oxidative stress markers by protecting the renal tissue from the cisplatin-induced lipid peroxidation $(3,7)$.

In another study, Sindhu and Kuttan applied lutein, a non-toxic carotenoid with strong antioxidant activity, to reduce cisplatin-induced renal damage in mice.

As shown by the reduction of serum urea and creatinine levels, nephrotoxicity, origi- 
nating from reduced activity of the antioxidant enzymes in the kidney (SOD, as well as CAT) and increased MDA levels, was reduced by lutein treatment (4). The results of this study showed that lutein might effectively protect the kidneys of mice treated with Cisplatin ${ }^{\circledR}$, which was also supported by the histopathologic evaluation of the kidney tissues of the treated animals. Last but not least, Ajith et al. gave $250 \mathrm{mg} / \mathrm{kg}$ or $500 \mathrm{mg} / \mathrm{kg}$ vitamins (ascorbic acid and alpha tocopherol) to their subjects to protect from the nephrotoxicty induced by Cisplatin ${ }^{\circledR}$ and they found that $500 \mathrm{mg} / \mathrm{kg}$ vitamins significantly protected the kidneys. However, the protective effect of vitamins from the cisplatin induced decline of activities of renal antioxidant enzymes such as SOD, CAT, GSHPx noted only in $500 \mathrm{mg} / \mathrm{kg}$ dosage group. Additionally, Authors have observed that both vitamins at dosages of 250 and $500 \mathrm{mg} / \mathrm{kg}$ could increase the concentration of reduced GSH and limit the extent of cisplatin-induced lipid peroxidation (8).

Recent data showed that herbal medicine might prevent some toxic effects of certain medications $(3,4,8-10)$. Phytotherapy on this aspect may be applied in a complementary fashion to ameliorate these effects. Majority of these phytotherapeutic agents have diuretic, anti-inflammatory, antioxidant and vasodilating effects. The active ingredients like essential oils, flavonoids, saponins, xanthine derivatives and glycosides were found responsible of these protective effects (23-25).

In a study, administration of plant extract mixtures produced improvements in biochemical, histopathological and cytogenetic parameters (26).

Other similar studies focused on the possible protective effects of plant extracts with certain ingredients demonstrating the protective effects on both the kidney as well as their specific protective effects on other pathologies in different organ systems $(27,28)$. Antioxidant, diuretic and antidiabetic effects of such agents also might be effective in limiting the toxic effects induced by Cisplatin ${ }^{\circledR}$ administration.

Taking into account the established effects of antioxidants as well as anti-inflammatory agents in the prevention of ischemia-induced injury in renal tubular epithelium, we aimed to evaluate the possible limitation of the extent of oxidative stress resulting from cisplatininduced toxicity by using a potential antioxidant and anti-inflammatory agent $\left(\right.$ Tutukon $\left.^{\circledR}\right)$ in a rat model.

Tutukon $^{\circledR}$ (Grand Medical, Spain) is a medication composed of different herbal ingredients demonstrating certain biological effects in tissues. Among these effects, the antioxidant potential is one of the most important characteristics of this drug due to its active ingredients. Among the eight different ingredients of Tutukon ${ }^{\circledR}$, alkaloids rosmarinic acid, flavonoids, apigenin, luteolin, ekvizetonin saponin, and essential oils are well known for their antioxidant as well as anti-inflammatory effects shown in different studies $(23,25,29)$. Regarding the mechanism of action, studies showed that these active ingredients may reduce the permeability of kidney capillaries, dilate kidney blood vessels and ureters, restore the tubular epithelial function, induce an osmotic effect, inhibit synthesis and activation of inflammatory mediators and thus prevent inflammatory alterations $(24,30)$.
Our current findings clearly showed that pre-treatment with this herbal product also might significant reduction in MDA levels and significant elevation of CAT activities and GSH levels of the renal tissues in cisplatin-treated rats. Evaluation of the antioxidant enzyme (Catalase and GSHPX) content revealed significant reduction in renal tissues of cisplatin-treated rats compared with the control group as well as in the groups receiving Tutukon ${ }^{\circledR}$. These findings may provide evidence of the antioxidant effect of Tutukon ${ }^{\circledR}$ against cisplatin-induced oxidative stress and lipid peroxidation. Parallel to the data reported in the literature so far, we found that reduction in the activity of antioxidant enzyme (CAT), increased lipid peroxidation (MDA) and depletion of GSH in renal tissues were implicated in the pathogenesis of Cisplatin ${ }^{\circledR}$ nephrotoxicity.

Our results also showed that ischemia-induced oxidative stress in renal tubules as well as the inflammatory changes might be the major underlying causes of cisplatin-induced renal functional as well as morphologic deterioration. Tutukon ${ }^{\circledR}$ with its potent ingredients may be protective in the limitation of such alterations at least in experimental models.

As a conclusion, Tutukon ${ }^{\circledR}$ showed an ameliorative effect against cisplatin-induced oxidative stress and renal damage through its antioxidant, anti-inflammatory and antiapoptotic properties. Due to the potential antioxidant activity, medicinal plants and natural herbal products like Tutukon ${ }^{\circledR}$ may be used as natural dietary antioxidants in protecting the kidney from damage originating from certain chemical agents. However, further studies with larger series of patients under clinical conditions are certainly needed.

\section{REFERENCES}

1. Miller RP, Tadagavadi RK, Ramesh $G$, et al. Mechanisms of Cisplatin nephrotoxicity. Toxins. 2010; 2:2490-518.

2. Karasawa T, Steyger PS. An integrated view of cisplatin-induced nephrotoxicity and ototoxicity. Toxicol Lett. 2015; 237:219-27.

3. Maliakel DM, Kagiya TV, Nair CK. Prevention of cisplatininduced nephrotoxicity by glucosides of ascorbic acid and alphatocopherol. Exp Toxicol Pathol. 2008; 60:521-7.

4. Sindhu ER, Kuttan R. Carotenoid lutein protects the kidney against cisplatin-induced acute renal failure. J Environ Pathol Toxicol Oncol. 2013; 32:21-8.

5. Kruidering M, Van de Water B, de Heer E, et al. Cisplatininduced nephrotoxicity in porcine proximal tubular cells: mitochondrial dysfunction by inhibition of complexes I to IV of the respiratory chain. J Pharmacol Exp Ther. 1997; 280:638-49.

6. Malik S, Suchal K, Gamad N, et al. Telmisartan ameliorates cisplatin-induced nephrotoxicity by inhibiting MAPK mediated inflammation and apoptosis. Eur J Pharmacol. 2015; 748:54-60.

7. Atasayar S, Gurer-Orhan H, Orhan H, et al. Preventive effect of aminoguanidine compared to vitamin $E$ and $C$ on cisplatin-induced nephrotoxicity in rats. Exp Toxicol Pathol. 2009; 61:23-32.

8. Ajith TA, Usha S, Nivitha V. Ascorbic acid and alpha-tocopherol protect anticancer drug cisplatin induced nephrotoxicity in mice: a comparative study. Clin Chim Acta. 2007;375:82-6.

9. Naqshbandi A, Rizwan S, Khan MW, et al. Dietary flaxseed oil 
supplementation ameliorates the effect of cisplatin on brush border membrane enzymes and antioxidant system in rat intestine. Hum Exp Toxicol. 2013; 32:385-94.

10. Razo-Rodriguez AC, Chirino YI, Sanchez-Gonzalez DJ, et al. Garlic powder ameliorates cisplatin-induced nephrotoxicity and oxidative stress. J Med Food. 2008; 11:582-6.

11. Prabhu VV, Kannan N, Guruvayoorappan C. 1,2-Diazole prevents cisplatin-induced nephrotoxicity in experimental rats. Pharmacol Rep. 2013; 65:980-90.

12. Ohkawa H, Ohishi N, Yagi K. Assay for lipid peroxides in animal tissues by thiobarbituric acid reaction. Anal Biochem. 1979; 95:351-8.

13. Beutler E. Red cell metabolism: a manual of biochemical methods. 2d ed. New York: Grune \& Stratton; 1975.

14. Aebi H. Catalase in vitro. Methods Enzymol. 1984; 105:121-6.

15. Sun Y, Oberley LW, Li Y. A simple method for clinical assay of superoxide dismutase. Clin Chem. 1988; 34: 497-500.

16. Ellman GL. Tissue sulfhydryl groups. Arch Biochem Biophys. 1959; 82:70-7.

17. Lowry OH, Rosebrough NJ, Farr AL, et al. Protein measurement with the Folin phenol reagent. J Biol Chem. 1951; 193:265-75.

18. Yang Y, Liu H, Liu F, et al. Mitochondrial dysregulation and protection in cisplatin nephrotoxicity. Arch Toxicol. 2014; 88:1249-56.

19. Fukasawa H, Furuya R, Yasuda H, et al. Anti-cancer agentinduced nephrotoxicity. Anticancer Agents Med Chem. 2014; 14:921-7.

20. Yonezawa A, Masuda S, Nishihara K, et al. Association between tubular toxicity of cisplatin and expression of organic cation transporter rOCT2 (Slc22a2) in the rat. Biochem Pharmacol. 2005; 70:1823-31.
21. Levi J, Jacobs C, Kalman SM, et al. Mechanism of cis-platinum nephrotoxicity: I. Effects of sulfhydryl groups in rat kidneys. J Pharmacol Exp Ther. 1980; 213:545-50.

22. Arany I, Safirstein RL. Cisplatin nephrotoxicity. Semin Nephrol. $2003 ; 23: 460-4$

23. Zadra M, Piana M, Brum TF, et al. Antioxidant Activity and phytochemical composition of the leaves of Solanum guaraniticum A. St.-Hil. Molecules. 2012; 17:12560-74.

24. Calixto JB, Santos AR, Cechinel Filho V, et al. A review of the plants of the genus Phyllanthus: their chemistry, pharmacology, and therapeutic potential. Medicinal Res Rev. 1998; 18:225-58.

25. Wang H, Yang L, Zu Y, et al. Microwave-assisted simultaneous extraction of luteolin and apigenin from tree peony pod and evaluation of its antioxidant activity. ScientificWorldJournal. 2014; 2014:506971.

26. Al-Okbi SY, Mohamed DA, Hamed TE, et al. Prevention of renal dysfunction by nutraceuticals prepared from oil rich plant foods. Asian Pac J Trop Biomed. 2014; 4:618-27.

27. Conner TA, McQuade C, Olp J, et al. Effect of intravenous vitamin $C$ on cytokine activation and oxidative stress in end-stage renal disease patients receiving intravenous iron sucrose. Biometals. 2012; 25:961-9.

28. Mimica-Dukic N, Simin N, Cvejic J, et al. Phenolic compounds in field horsetail (Equisetum arvense L.) as natural antioxidants. Molecules. 2008; 13:1455-64.

29. Xi M, Hai C, Tang H, et al. Antioxidant and antiglycation properties of total saponins extracted from traditional Chinese medicine used to treat diabetes mellitus. Phytother Res. 2008; 22:228-37.

30. Calixto JB, Yunes RA, Neto AS, et al. Antispasmodic effects of an alkaloid extracted from Phyllanthus sellowianus: a comparative study with papaverine. Braz J Med Biol Res. 1984; 17:313-21.

\section{Correspondence}

Eyup Veli Kucuk, MD

eyupveli@gmail.com

Umraniye Training and Research Hospital Urology Clinic,

Istanbul, Turkey

Ahmet Bindayi, MD, FEBU

ahmetbindayi@gmail.com

Bahcesehir University Department of Urology, Istanbul, Turkey

Meral Mese, $M D$

mesemera@gmail.com

Funda Gulcu Bulmus, MD

fundagulcu@yahoo.com.tr

Ergun Parmaksiz, MD

drergnprmksz@hotmail.com

Zerrin Bicik Bahcebasi, MD

zerrinbicik@yahoo.com

Dr. Lütfi Kirdar Training and Research Hospital Nephrology Clinic,

Istanbul, Turkey

Ali Cihangir Cetinel, MD

cihangircetinel@gmail.com

Kemal Sarica, MD

saricakemal@gmail.com

Dr. Lütfi Kirdar Training and Research Hospital Urology Clinic, Istanbul, Turkey 